DOI: 10.18276/sip.2016.45/1-17

\title{
Leszek Dawid*
}

Politechnika Koszalińska

\section{UŻYTKOWANIE WIECZYSTE GRUNTÓW SKARBU PAŃSTWA W LATACH 2010-2015 NA PRZYKŁADZIE POWIATU KOSZALIŃSKIEGO}

\section{Streszczenie}

Użytkowanie wieczyste jest prawem rzeczowym, które umożliwia korzystanie z gruntów państwowych i samorządowych. Forma ta stanowi prawo pośrednie między prawem własności a ograniczonymi prawami rzeczowymi. W artykule zbadano nieruchomości stanowiące własność Skarbu Państwa na obszarze powiatu koszalińskiego w latach 2010-2015. Na terenie objętym badaniami w analizowanym okresie w użytkowanie wieczyste oddanych było od 473 (2010 r.) do 414 (2015 r.) nieruchomości stanowiących własność Skarbu Państwa. Znajdowały się one na obszarze 11 gmin. Celem opracowania jest analiza danych dotycząca liczby, powierzchni, wartości nieruchomości oddanych w użytkowanie wieczyste różnym podmiotom oraz opłat za użytkowanie wieczyste. Badania przeprowadzono na podstawie danych ilościowych otrzymanych ze Starostwa Powiatowego w Koszalinie.

Słowa kluczowe: użytkowanie wieczyste, koszalińskie starostwo powiatowe

\section{Wstęp}

Użytkowanie wieczyste jest prawem rzeczowym, które uprawnia do korzystania z gruntów państwowych i samorządowych. Forma ta stanowi prawo pośrednie między prawem własności a ograniczonymi prawami rzeczowymi. Polega na uprawnieniu użytkownika wieczystego do korzystania z gruntu mu oddanego z wyłącze-

\footnotetext{
Adres e-mail: leszek.dawid@tu.koszalin.pl.
} 
niem innych osób oraz do rozporządzenia tym prawem. Użytkownik wieczysty ma prawo korzystać z gruntu i nim rozporządzać na prawach zbliżonych do prawa własności. Powinien również wypełniać obowiązki podatkowe oraz utrzymać nieruchomość w należytym stanie. Według danych GUS (2015) w 2014 roku liczba transakcji kupna-sprzedaży nieruchomości w Polsce z prawem użytkowania wieczystego do działki wynosiła około 8900 , co stanowiło ponad $10 \%$ ogólnej liczby transakcji. Prawo to zostało wprowadzone do polskiego sytemu prawnego ustawą z 14 lipca 1961 roku o gospodarce terenami w miastach i osiedlach (Ustawa, 1961). Obecnie prawo użytkowania wieczystego znajduje swoją regulację w art. 232-243 ustawy z 23 kwietnia 1964 roku - Kodeks cywilny (Ustawa, 1964), ustawie z 21 sierpnia 1997 roku o gospodarce nieruchomościami (Ustawa, 1997), ustawie z 29 lipca 2005 roku o przekształceniu prawa użytkowania wieczystego w prawo własności (Ustawa, 2005).

Ze względu na wzrost cen nieruchomości w czasie - zwłaszcza w tak długim okresie, jakim jest użytkowanie wieczyste - powinna być dokonywana aktualizacja opłat rocznych z tytułu użytkowania wieczystego gruntów Skarbu Państwa oraz jednostek samorządu terytorialnego - art. 77 ust. (Ustawa, 1997). Wysokość stawki procentowej tej opłaty uzależniona jest od celu, na jaki grunt został oddany do zagospodarowania, i może wynosić: $0,3 \%, 1 \%, 2 \%, 3 \%$. Zmiana wartości rynkowej nieruchomości może nastąpić na skutek upływu czasu, co powinien wykazać rzeczoznawca majątkowy w operacie szacunkowym. Zgodnie z art. 77 (Ustawa, 1997) aktualizację opłaty rocznej z tytułu użytkowania nieruchomości można przeprowadzić z urzędu lub na wniosek użytkownika wieczystego na podstawie wartości nieruchomości gruntowej określonej przez rzeczoznawcę majątkowego. Do 9 października 2011 roku właściciel gruntu mógł przeprowadzać aktualizację opłat rocznych nie częściej niż raz w roku, a po tym okresie nie częściej niż raz na 3 lata (Źróbek, Kuryj, Kuryj-Wysocka, 2015). W przypadku nieruchomości oddanych na cele mieszkaniowe - raz na 5 lat. Istotnym aspektem analizy rynku nieruchomości jest próba zdefiniowania czynników wpływających na rynek nieruchomości mieszkaniowych (Mach, 2014), jak również aspekty użytkowania wieczystego, o którym traktuje niniejszy artykuł. Analiza aktualizacji opłat za użytkowanie wieczyste nieruchomości przez gminy była tematem wielu opracowań (np. Kucharska-Stasiak, Ledzion-Trojanowska, Szopiński, Żelazowski, 2006; Kokot, 2006, 2009; Kwartnik-Pruc, Trembecka, 2015). W niniejszym opracowaniu podjęto próbę przedstawienia tej problematyki, ale w odniesieniu do gruntów Skarbu Państwa na terenie wybranego powiatu. 
W artykule poddano badaniom nieruchomości stanowiące własność Skarbu Państwa na obszarze powiatu koszalińskiego w latach 2010-2015. Na terenie objętym badaniami w analizowanym okresie w użytkowanie wieczyste oddanych było od 473 (2010 r.) do 414 (2015 r.) nieruchomości stanowiących własność Skarbu Państwa. Znajdowały się one na obszarze 11 gmin. Celem pracy jest analiza danych liczbowych dotycząca powierzchni, wartości nieruchomości oddanych w użytkowanie wieczyste różnym podmiotom oraz analiza aktualizacji opłat za użytkowanie wieczyste dotycząca wybranych podmiotów. Artykuł ma charakter przeglądowo-informacyjny. Badania przeprowadzono na podstawie danych ilościowych otrzymanych ze Starostwa Powiatowego w Koszalinie. W badaniach zastosowano technikę analizy ilościowej i jakościowej dokumentów oraz analizę opisową. Podstawą doboru metod analizy był rodzaj uzyskanych informacji.

\section{Obszar badań}

Powiat koszaliński położony jest w północno-wschodniej części województwa zachodniopomorskiego. Liczy około 64200 mieszkańców. Jego ogólna powierzchnia wynosi $1669 \mathrm{~km}^{2}$, z czego 34,1\% zajmują grunty orne, 42,8\% - lasy i tereny leśne, a 23,1\% - pozostałe grunty. W skład powiatu wchodzą następujące gminy: Bobolice, Polanów i Sianów o statusie miejsko-wiejskim, a także Będzino, Biesiekierz, Manowo, Mielno i Świeszyno o statusie wiejskim. Powiat koszaliński od zachodu sąsiaduje z powiatem kołobrzeskim, od południowego zachodu z białogardzkim, od południa ze szczecineckim, od wschodu z bytowskim, zaś od północnego wschodu ze sławieńskim. Północną granicę powiatu wyznacza około 30-kilometrowy pas wybrzeża Bałtyku. Obszar badań przedstawiono na rysunku 1. 
Rysunek 1. Mapa części województwa zachodniopomorskiego z powiatami i gminami

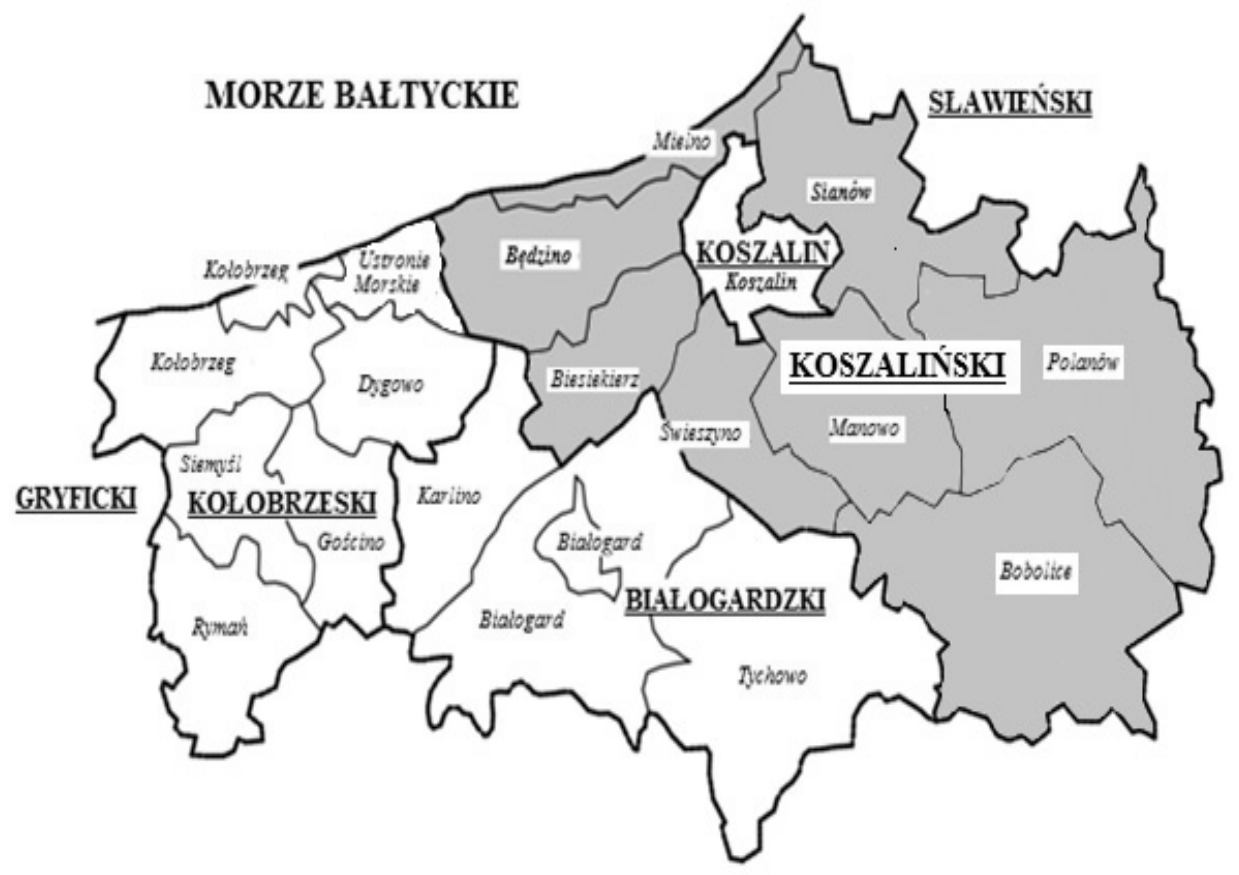

Źródło: opracowanie własne.

\section{Ogólna charakterystyka nieruchomości Skarbu Państwa oddanych w użytkowanie wieczyste w powiecie koszalińskim}

Na podstawie danych uzyskanych ze Starostwa Powiatowego w Koszalinie stwierdzono, że na terenie badań w analizowanym okresie w użytkowanie wieczyste oddanych było od 743 działek (2010 r.) do 790 działek (2015 r.). Stanowiły one 46\% zasobu gruntów Skarbu Państwa na analizowanym terenie na 31 grudnia 2010 roku i 42\% na koniec 2015 roku, co przedstawiono w tabeli 1 i na rysunku 2. Zajmowały one obszar od 638,7682 ha (2010 r.) do 567,5391 ha (2015 r.), co stanowiło odpowiednio 34 i 20\% powierzchni zasobu gruntów Skarbu Państwa. W analizowanych latach na terenie badawczym najwięcej gruntów było oddanych w trwały zarząd $-47 \%$ w 2010 roku i 57\% w 2015 roku. Najwyższe wpływy były jednak z tytułu użytkowania wieczystego i wynosiły w 2010 roku około 349 tys. zł (rys. 3), co stanowiło 99\% wszystkich opłat za grunty Skarbu Państwa w powiecie koszalińskim. W 2015 roku 
wpływy z tytułu użytkowania wieczystego wynosiły około 510 tys. zł, co stanowiło 94\% wszystkich opłat.

Tabela 1. Zasób nieruchomości gruntów Skarbu Państwa w powiecie koszalińskim na 31 grudnia 2010 r. i 31 grudnia 2015 r.

\begin{tabular}{|c|c|c|c|c|c|}
\hline Lata & $\begin{array}{c}\text { Wybrane } \\
\text { charakterystki }\end{array}$ & $\begin{array}{l}\text { Użytkowanie } \\
\text { wieczyste }\end{array}$ & Trwały zarząd & $\begin{array}{l}\text { Pozostały } \\
\text { zasób }\end{array}$ & Razem \\
\hline \multirow{5}{*}{$\stackrel{\circ}{\stackrel{0}{\circ}}$} & \multicolumn{5}{|c|}{ Działki } \\
\hline & Liczba/\% & $743 / 46$ & $311 / 19$ & $557 / 35$ & $1611 / 100$ \\
\hline & $\begin{array}{l}\text { Powierzchnia } \\
\left(\mathrm{m}^{2}\right) / \%\end{array}$ & $638768 / 34$ & $8777506 / 47$ & $3602041 / 17$ & $18767229 / 100$ \\
\hline & Wartość (zł)/\% & $17596632,08 / 92$ & $1328370,48 / 7$ & $124071,58 / 1$ & $19049074,14 / 100$ \\
\hline & $\begin{array}{l}\text { Suma opłat } \\
\text { (zł) } / \%\end{array}$ & $348944,67 / 99$ & $3502,24 / 1$ & $590,53 / 0$ & $353037,44 / 100$ \\
\hline \multirow{4}{*}{$\frac{n}{2}$} & Liczba/\% & $790 / 42$ & $377 / 20$ & $723 / 38$ & $1890 / 100$ \\
\hline & $\begin{array}{l}\text { Powierzchnia } \\
\left(\mathrm{m}^{2}\right) / \%\end{array}$ & $5675391 / 20$ & $15459895 / 53$ & $7873669 / 27$ & $29008955 / 100$ \\
\hline & Wartość (zł)/\% & $27556790,91 / 68$ & $12562504,03 / 31$ & $129792,98 / 1$ & $40249087,92 / 100$ \\
\hline & $\begin{array}{l}\text { Suma opłat } \\
\text { (zł) } / \%\end{array}$ & $509552,14 / 94$ & $32618,17 / 6$ & $519,98 / 0$ & $542690,29 / 100$ \\
\hline
\end{tabular}

Źródło: opracowanie własne na podstawie danych uzyskanych ze Starostwa Koszalińskiego.

Rysunek 2. Liczba działek Skarbu Państwa oddanych w użytkowanie wieczyste, trwały zarząd i pozostały zasób w powiecie koszalińskim w latach 2010-2015

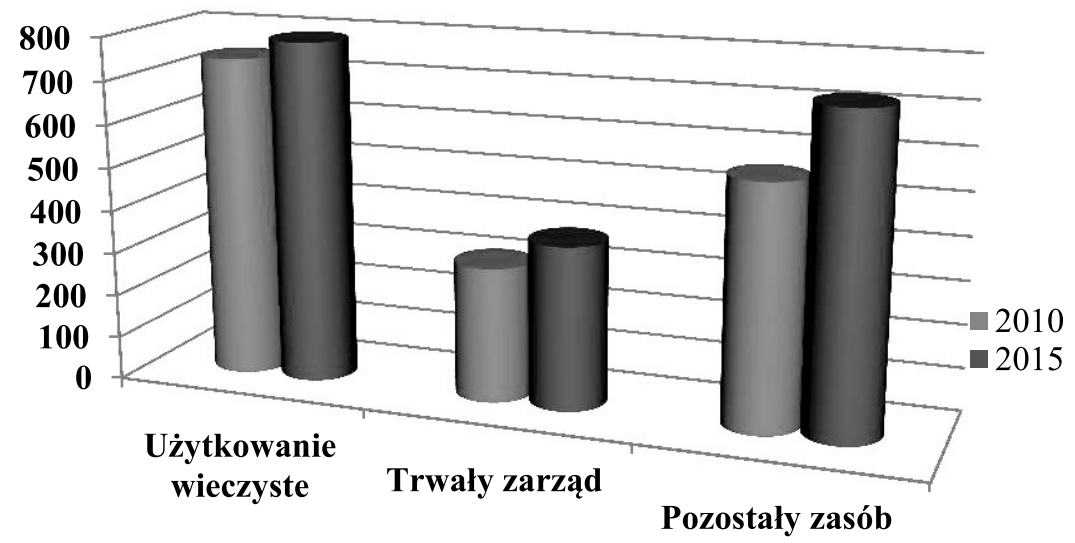

Źródło: opracowanie własne na podstawie danych uzyskanych ze Starostwa Koszalińskiego. 
Na 31 grudnia 2015 roku na analizowanym terenie około $18 \%$ powierzchni zasobu było oddane w użytkowanie wieczyste osobom fizycznym, około 37\% - państwowym osobom prawnym i około $45 \%$ - pozostałym osobom prawnym, w tym: gminom (ok. 14\%), spółdzielniom (ok. 6\%), Enerdze (ok. 38\%), Zakładowi Energetycznemu (ok. 2\%), pozostałym (ok. 40\%), co przedstawiono w tabeli 2. Pod względem wartości nieruchomości największy udział miały pozostałe osoby prawne (ok. 53\% ogółu) i osoby fizyczne (ok. 46\%). Podobnie wyglądały udziały w przypadku opłat rocznych.

Rysunek 3. Suma opłat gruntów Skarbu Państwa oddanych w użytkowanie wieczyste, trwały zarząd i pozostały zasób na terenach gmin powiatu koszalińskiego w latach 2010-2015

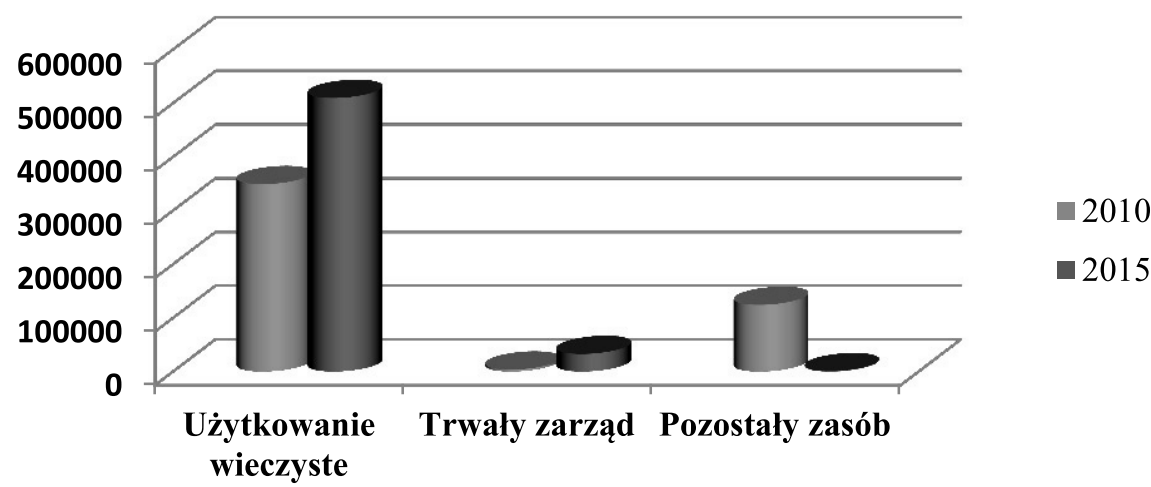

Źródło: opracowanie własne na podstawie danych uzyskanych ze Starostwa Koszalińskiego.

Tabela 2. Zasób nieruchomości gruntów Skarbu Państwa oddanych w użytkowanie wieczyste z podziałem na osoby fizyczne, prawne i pozostałe osoby prawne w powiecie koszalińskim na 31 grudnia $2015 \mathrm{r}$.

\begin{tabular}{|l|c|c|c|c|c|c|c|c|}
\hline & \multirow{2}{*}{$\begin{array}{c}\text { Osoby } \\
\text { fizyczne }\end{array}$} & \multirow{2}{*}{$\begin{array}{c}\text { Państwowe } \\
\text { osoby prawne }\end{array}$} & \multicolumn{6}{|c|}{ Pozostałe osoby prawne } \\
\cline { 5 - 10 } & & & $\mathrm{R}$ & $\mathrm{S}$ & $\mathrm{E}$ & $\mathrm{ZE}$ & $\mathrm{P}$ \\
\hline Powierzchnia (\%) & 18 & 37 & 45 & 14 & 6 & 38 & 2 & 40 \\
\hline Wartość (\%) & 46 & 1 & 53 & 2 & 35 & 10 & 2 & 51 \\
\hline Opłaty roczne (\%) & 47 & 0 & 53 & 2 & 29 & 6 & 1 & 62 \\
\hline
\end{tabular}

Oznaczenia: R - razem, G - gminy, S - spółdzielnie, E - Energa, ZE - Zakład Energetyczny, P - pozostałe.

Źródło: opracowanie własne na podstawie danych uzyskanych ze Starostwa Koszalińskiego. 


\section{Ogólna charakterystyka nieruchomości Skarbu Państwa oddanych w użytkowanie wieczyste w powiecie koszalińskim, leżących w poszczególnych gminach}

W analizowanym okresie na terenie badawczym znajdowało się od 473 (2010 r.) do 414 (2015 r.) nieruchomości stanowiących własność Skarbu Państwa. Usytuowane one były na obszarze wszystkich gmin należących do powiatu koszalińskiego. Najwięcej nieruchomości stanowiących własność Skarbu Państwa z prawem użytkowania wieczystego znajdowało się w gminie Mielno [105 (2010-2012)], najmniej w gminie Polanów-miasto [9 (2013-2015)]. W większości przypadków analizowanych gmin liczba działek i nieruchomości zmniejszała się, oprócz gmin: Biesiekierz, Manowo i Sianów-obszar wiejski. W gminie Będzino liczba działek w analizowanym okresie zmalała o około $16 \%$, a nieruchomości o około $12 \%$. Podobna tendencja występowała także w gminie Bobolice-miasto - spadek liczby był o około 16\%, a nieruchomości o około 13\%, w gminie Bobolice-obszar wiejski odpowiednio: o około 9 i 41\%, w gminie Mielno - o około 13 i 22\%, w gminie Polanów-miasto - o około 6 i 10\%, w gminie Polanów-obszar wiejski-o około 0 i 5\%, Sianów-miasto - o około 6 i 10\%, Świeszyno - o około 3 i $5 \%$. Wzrosła liczba działek w gminie Biesiekierz o około 15\%, a nieruchomości o około 20\%, w Sianowie-obszar wiejski odpowiednio o około 4 i 3\%. Liczba działek najbardziej wzrosła w gminie Manowo, bo aż o około $67 \%$, ale liczba spadła nieruchomości o około $8 \%$. Średnią liczbę działek w analizowanym okresie przedstawiono na rysunku 4. Średnio najwięcej działek będących w użytkowaniu wieczystym znajdowało się w gminie Manowo - ponad 250, a nieruchomości w gminie Mielno - prawie 100. Średnio najmniej działek znajdowało się w gminie Biesiekierz - około 14, a nieruchomości w gminie Polanów-miasto - około 10.

Pod względem wartościowym w analizowanym okresie wpływy z tytułu użytkowania gruntów Skarbu Państwa były bardzo zróżnicowane, co przedstawiono na rysunku 5. Najwyższe były na terenie gminy Mielno i wynosiły w analizowanym okresie w sumie ponad 855 tys. zł, najniższe w gminie Polanów-obszar wiejski około 460 zł. Wpływy w latach 2010-2015 co roku wzrastały od około 349 tys. zł w 2010 roku do około 510 tys. zł w 2015 roku. Najwyższy wpływ roczny był w 2012 roku w gminie Mielno i wynosił ponad 180 tys. zł. Średnia cena za $1 \mathrm{~m}^{2}$ była również bardzo zróżnicowana. Najwyższe ceny średnie (rys. 6) za działki oddane w użytkowanie wieczyste $\mathrm{w}$ analizowanym okresie były na terenie gminy Biesiekierz - ponad $50 \mathrm{zz} / \mathrm{m}^{2}$, następnie w gminach Manowo i Bobolice-obszar wiejski (ok. $35 \mathrm{zz} / \mathrm{m}^{2}$ ), Mielno (ponad $25 \mathrm{zt} / \mathrm{m}^{2}$ ), Bobolice-miasto (ok. $24 \mathrm{zz} / \mathrm{m}^{2}$ ). Najniższe były w gminie Polanów-miasto i wynosiły zaledwie kilkanaście groszy za $1 \mathrm{~m}^{2}$. W pozostałych analizowanych gminach zawierały się w przedziale od $5 \mathrm{do} 15 \mathrm{z} / \mathrm{m}^{2}$. 
Rysunek 4. Średnia liczba działek i nieruchomości Skarbu Państwa oddanych w użytkowanie wieczyste na terenach gmin powiatu koszalińskiego w latach 2010-2015

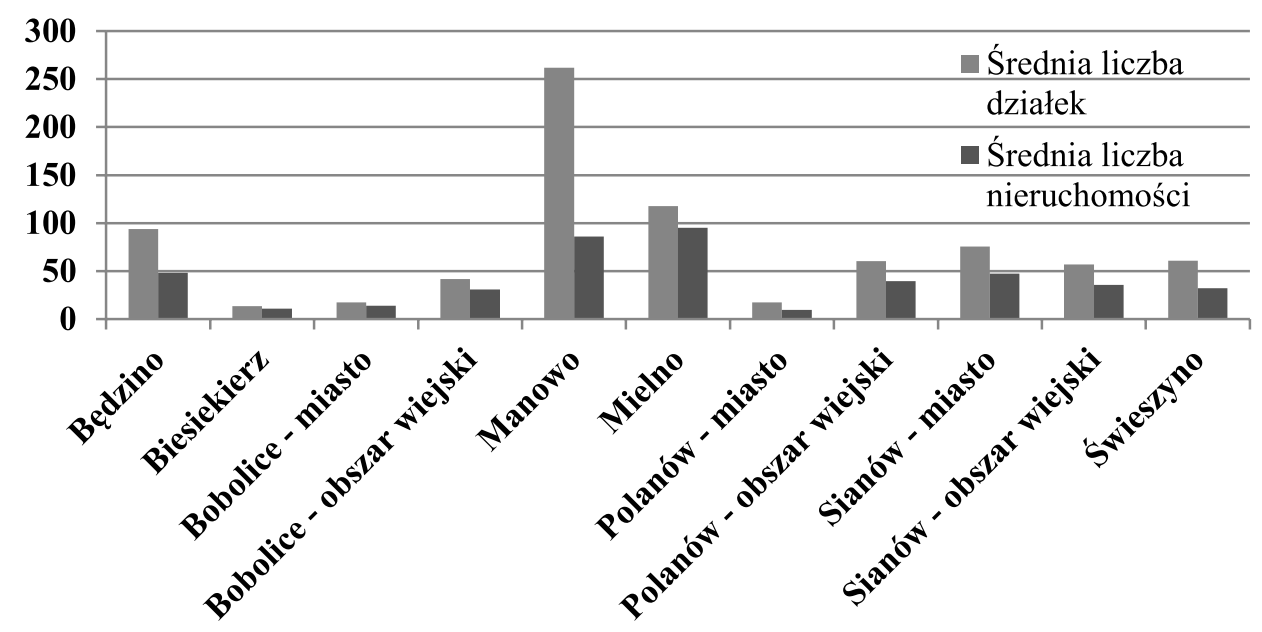

Źródło: opracowanie własne na podstawie danych uzyskanych ze Starostwa Koszalińskiego.

Rysunek 5. Suma opłat Skarbu Państwa nieruchomości oddanych w użytkowanie wieczyste na terenach gmin powiatu koszalińskiego w latach 2010-2015

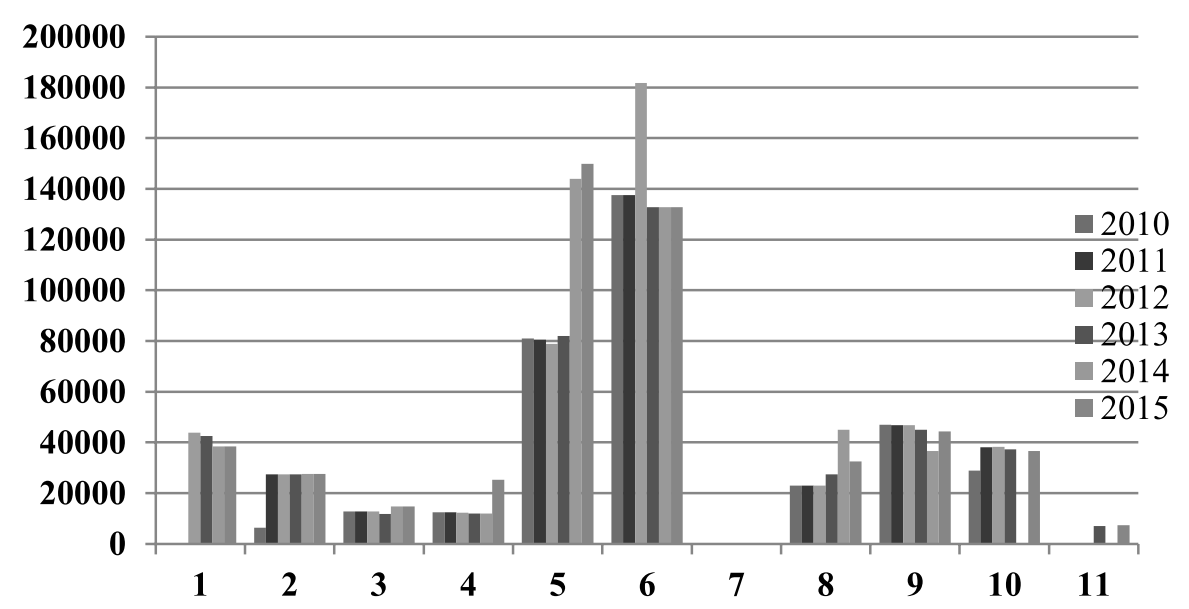

Oznaczenia gmin: 1 - Będzino, 2 - Biesiekierz, 3 - Bobolice-miasto, 4 - Bobolice-obszar wiejski, 5 - Manowo, 6 - Mielno, 7 - Polanów-miasto, 8 - Polanów-obszar wiejski, 9 - Sianów-miasto, 10 Sianów-obszar wiejski, 11 - Świeszyno.

Źródło: opracowanie własne na podstawie danych uzyskanych ze Starostwa Koszalińskiego. 
Rysunek 6. Średnia cena za $1 \mathrm{~m}^{2}$ działek Skarbu Państwa oddanych w użytkowanie wieczyste na terenach gmin powiatu koszalińskiego w latach 2010-2015

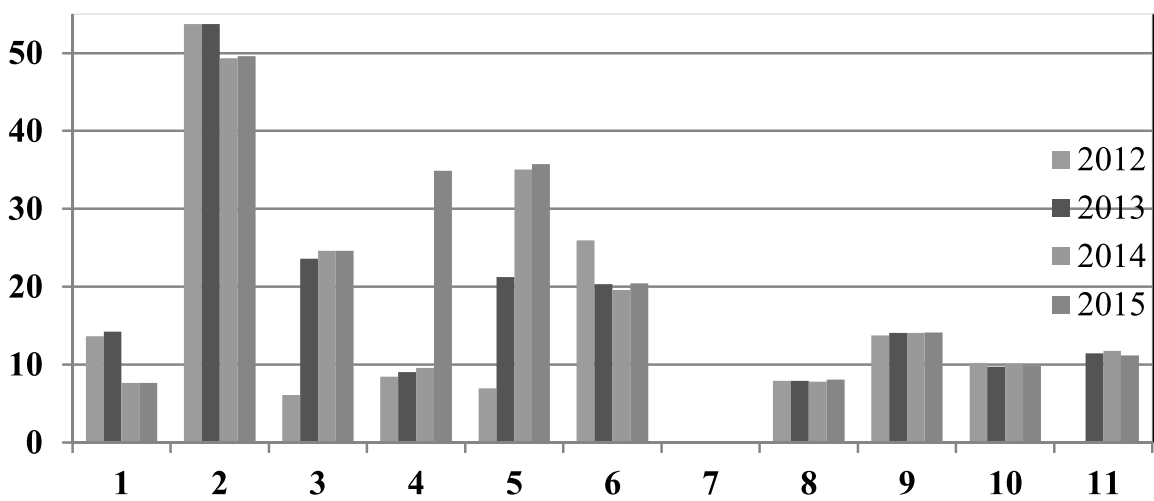

Oznaczenia gmin: 1 - Będzino, 2 - Biesiekierz, 3 - Bobolice-miasto, 4 - Bobolice-obszar wiejski, 5 - Manowo, 6 - Mielno, 7 - Polanów-miasto, 8 - Polanów-obszar wiejski, 9 - Sianów-miasto, 10 - Sianów-obszar wiejski, 11 - Świeszyno. Źródło: opracowanie własne na podstawie danych uzyskanych ze Starostwa Koszalińskiego.

\section{Analiza aktualizacji opłat rocznych użytkowania wieczystego nieruchomości Skarbu Państwa oddanych w użytkowanie wieczyste dla wybranych podmiotów powiatu koszalińskiego}

Na podstawie informacji uzyskanych ze Starostwa Powiatowego w Koszalinie stwierdzono, że w analizowanym okresie średnio oddanych w użytkowanie wieczyste było około 770 działek. Występowało w tym okresie na terenie badawczym pięć stawek procentowych opłat: $0 \%$ (średnio ok. 44\% ogółu), 0,3\% - 1 działka (parafia Kłanino), 1\% (średnio ok. 33\% ogółu), 2\% (średnio ok. 1\% ogółu), 3\% (średnio ok. $21 \%$ ogółu). W tabeli 3 przedstawiono stawki procentowe w wysokości 1 i 3\% oraz terminy aktualizacji opłat za użytkowanie wieczyste dla wybranych następujących podmiotów: osoby fizyczne, osoby prawne z podziałem na spółdzielnie, gminy, Energa i Zakład Energetyczny (ze względu na znaczący udział pod względem wartościowym i ilościowym w analizowanej próbie badawczej). Na analizowanym terenie w latach 2010-2015 dokonano aktualizacji tylko części opłat. 
Tabela 3. Aktualizacja opłat za użytkowanie wieczyste dla wybranych podmiotów

\begin{tabular}{|c|c|c|c|c|c|c|}
\hline & & $\begin{array}{l}\text { Osoby } \\
\text { fizyczne }\end{array}$ & Spółdzielnie & Gminy & Energa & $\begin{array}{c}\text { Zakład } \\
\text { Energetyczny }\end{array}$ \\
\hline $\begin{array}{l}\text { Stawki } \\
(\%)\end{array}$ & $\begin{array}{c}\text { Liczba } \\
\text { nieruchomości } \\
\text { razem }\end{array}$ & 63 & 68 & 17 & 25 & 51 \\
\hline \multirow[b]{2}{*}{ 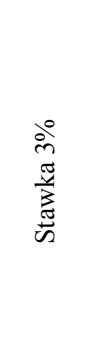 } & Liczba & 27 & 6 & 5 & 5 & 2 \\
\hline & $\begin{array}{l}\text { Data ostatniej } \\
\text { aktualizacji } \\
\text { - liczba w \% }\end{array}$ & $\begin{array}{c}2000-3,7 \\
2005-7,4 \\
2006-3,7 \\
2009-25,9 \\
2010-14,9 \\
2012-7,4 \\
2013-7,4 \\
2014-25,9 \\
2015-3,7\end{array}$ & $\begin{array}{c}2003-16,7 \\
2013-49,99 \\
2014-33,4\end{array}$ & $\begin{array}{c}2009-40,0 \\
2012-20,0 \\
2014-20,0 \\
\text { b.d. }-20,0\end{array}$ & $\begin{array}{c}2009-40,0 \\
2012-20,0 \\
2014-20,0 \\
\text { b.d. }-20,0\end{array}$ & $2014-100,00$ \\
\hline \multirow[b]{2}{*}{$\frac{\stackrel{\circ}{\pi}}{\frac{\pi}{\pi}}$} & Liczba & 36 & 62 & 12 & 20 & 49 \\
\hline & $\begin{array}{l}\text { Data ostatniej } \\
\text { aktualizacji } \\
\text { - Liczba w \% }\end{array}$ & $\begin{array}{c}2000-2,8 \\
2001-2,8 \\
2005-13,8 \\
2008-2,8 \\
2009-42 \\
2010-13,8 \\
2012-13,8 \\
2013-8,2\end{array}$ & $\begin{array}{c}2003-27,4 \\
2005-3,2 \\
2006-1,6 \\
2008-1,6 \\
2009-1,6 \\
2010-1,6 \\
2012-62,96\end{array}$ & $\begin{array}{c}2001-25,3 \\
2006-16,6 \\
2007-8,3 \\
2009-16,6 \\
2012-16,6 \\
2014-8,3 \\
\text { b.d. }-8,3\end{array}$ & $\begin{array}{c}2000-15,0 \\
2003-25,0 \\
2009-10,0 \\
2012-5,0 \\
2014-45,0\end{array}$ & $\begin{array}{c}2005-2,0 \\
2006-10,2 \\
2008-26,6 \\
2009-43,0 \\
2010-6,0 \\
2012-8,1 \\
\text { b.d. }-4,1\end{array}$ \\
\hline
\end{tabular}

Źródło: opracowanie własne na podstawie danych uzyskanych ze Starostwa Koszalińskiego.

W przypadku osób fizycznych i stawki procentowej 1\% aktualizacja dotyczyła tylko około $36 \%$ opłat. Około $20 \%$ opłat nie było aktualizowanych od kilkunastu lat. Większość opłat (ok. 42\%) była aktualizowana w 2009 roku. W przypadku wybranych osób prawnych aktualizacja wyglądała trochę lepiej. W latach 2010-2015 w przypadku spółdzielni było to około 65\%, ale około $27 \%$ miało miejsce w 2003 roku. W przypadku gmin aktualizacja około $25 \%$ opłat miała miejsce w 2001 roku, a w okresie 2006-2009 dotyczyła około 42\%. W analizowanym okresie w gminach zaktualizowano około $25 \%$ opłat. W przypadku Energi ostatnia aktualizacja miała miejsce w kilku etapach. Około 15\% opłat aktualizowano w 2000 roku, w 2003 roku - około $25 \%$, w 2009 roku - około 10\%, w analizowanym okresie około 50\%, z czego aż 45\% w 2014 roku. W przypadku Zakładu Energetycznego w latach 20052009 dokonano aktualizacji ponad 80\% opłat - najwięcej w 2009 roku (ok. 43\%). W latach 2010-2015 zaktualizowano około 15\% opłat. W przypadku działek z zastosowaną stawką procentową 3\% aktualizacja dotyczyła większej liczby opłat niż w przypadku stawki 1\%. Większość aktualizacji została przeprowadzona w latach 
2012-2014. W przypadku Zakładu Energetycznego aktualizacja w 100\% odbyła się w 2014 roku. W przypadku gmin i Energi 60\% aktualizacji wykonano w latach 2012-2014, a 40\% w 2009 roku. W przypadku osób fizycznych w analizowanym okresie zaktualizowano opłaty roczne dla 15 działek, co stanowiło około $60 \%$ ogółu. W latach 2000-2006 wykonano około 15\% aktualizacji, a w 2009 roku - około $26 \%$. Na skutek aktualizacji opłat następował bardzo wysoki ich wzrost, co można zobaczyć na rysunku 5 i w tabeli 3, choćby na przykładzie gminy Biesiekierz, gdzie średnia cena działek wzrosła ponad 10-krotnie na skutek nowej wyceny ich wartości w 2010 roku. Podobnie wyglądała sytuacja w gminach Bobolice-miasto, Bobolice-obszar wiejski, gdzie po aktualizacji w odpowiednio w 2011 i w 2014 roku średnia cena działek wzrosła 5-krotnie.

\section{Podsumowanie}

Na terenie badań w analizowanym okresie w użytkowanie wieczyste oddanych było od 743 działek (2010 r.) do 790 działek (2015 r.). Stanowiły one 46\% zasobu gruntów Skarbu Państwa na analizowanym terenie na 31 grudnia 2010 roku i 42\% na koniec 2015 roku. Zajmowały one obszar od 638,7682 ha (2010 r.) do 567,5391 ha (2015 r.), co stanowiło odpowiednio 34 i 20\% powierzchni zasobu gruntów Skarbu Państwa. Najwyższe wpływy były jednak z tytułu użytkowania wieczystego i wynosiły w 2010 roku około 349 tys. zł, co stanowiło 99\% wszystkich opłat za grunty Skarbu Państwa w powiecie koszalińskim. W 2015 roku wpływy z tytułu użytkowania wieczystego wynosiły około 510 tys. zł, co stanowiło $94 \%$ wszystkich opłat. Na 31 grudnia 2015 roku na analizowanym terenie około $18 \%$ powierzchni zasobu było oddane w użytkowanie wieczyste osobom fizycznym, około 37\% - państwowym osobom prawnym i około $45 \%$ - pozostałym osobom prawnym, w tym: gminom około $14 \%$, spółdzielniom - około 6\%, Enerdze - około 38\%, Zakładowi Energetycznemu - około 2\%, pozostałym - około 40\%. Pod względem wartości nieruchomości największy udział miały pozostałe osoby prawne (ok. 53\% ogółu) i osoby fizyczne (ok. 46\%).

Średnio najwięcej działek będących w użytkowaniu wieczystym było w gminie Manowo (ponad 250), a nieruchomości w gminie Mielno (prawie 100). Średnio najmniej działek znajdowało się w gminie Biesiekierz (ok. 14), a nieruchomości w gminie Polanów-miasto (ok. 10). Najwyższe ceny średnie za działki oddane w użytkowanie wieczyste $\mathrm{w}$ analizowanym okresie były na terenie gminy Biesiekierz (ponad $\left.50 \mathrm{zł} / \mathrm{m}^{2}\right)$, 
następnie w gminach Manowo i Bobolice-obszar wiejski (ok. $35 \mathrm{z} / \mathrm{m}^{2}$ ), Mielno (ponad $25 \mathrm{zz} / \mathrm{m}^{2}$ ), Bobolice-miasto (ok. 24 zł/ $/ \mathrm{m}^{2}$ ). Najniższe były w gminie Polanów-miasto i wynosiły zaledwie kilkanaście groszy za $1 \mathrm{~m}^{2}$. W pozostałych analizowanych gminach zawierały się w przedziale od 5 do $15 \mathrm{zz} / \mathrm{m}^{2}$.

W powiecie koszalińskim w latach 2010-2015 występowało pięć stawek procentowych opłat za użytkowanie wieczyste: $0 \%$ (średnio ok. 44\% ogółu), 0,3\%, 1\% (średnio ok. 33\% ogółu), 2\% (średnio ok. 1\% ogółu), 3\% (średnio ok. 21\% ogółu). $\mathrm{Na}$ analizowanym terenie w latach 2010-2015 dokonano aktualizacji tylko części opłat. W przypadku osób fizycznych i stawki procentowej 1\% aktualizacja dotyczyła zaledwie około 36\% działek. Część opłat (ok. 20\%) nie była aktualizowana od kilkunastu lat. W przypadku działek z zastosowaną stawką procentową 3\% aktualizacja dotyczyła większości opłat i została przeprowadzona w latach 2012-2014. Po aktualizacji opłat, wskutek nowej wyceny, średnia wartość działek wzrastała nawet ponad 10-krotnie (gmina Biesiekierz).

Istniejący $\mathrm{w}$ analizowanym okresie $\mathrm{w}$ powiecie koszalińskim stan rzeczy jest szkodliwy zarówno dla właściciela nieruchomości (Skarbu Państwa), jak i dla użytkownika wieczystego. Poprzez brak aktualizacji opłat do budżetu Skarbu Państwa wpływają niższe kwoty. $Z$ drugiej strony nieaktualizowanie opłat rocznych przez właściciela nieruchomości przez okres na przykład kilkunastu lat sprawia, że opłaty dla użytkowników wieczystych gwałtownie wzrastają nawet o kilkaset procent. Może to stanowić zbyt wysokie obciążenie zwłaszcza dla właścicieli nieruchomości komercyjnych, gdzie stawka procentowa opłaty wynosi 3\%. Przy tak dużych brakach aktualizacji opłat dobrym rozwiązaniem może być wprowadzenie kilku etapów aktualizacji jak w przypadku firmy Energa. Wydaje się, że wprowadzenie przez ustawodawcę minimalnej częstotliwości aktualizacji opłat w tym przypadku byłoby zalecane i prawidłowe.

\section{Literatura}

GUS (2015). Obrót nieruchomościami w $2014 r$. Warszawa.

Kokot, S. (2006). Statystyczna analiza wpływów z tytułu opłat za użytkowanie wieczyste gruntów w budżetach gmin województwa zachodniopomorskiego. Zeszyty Naukowe Uniwersytetu Szczecińskiego, 450, Prace Katedry Ekonometrii i Statystyki, 17, 297-306.

Kokot, S. (2009). Ekonomiczne aspekty użytkowania wieczystego w gospodarce nieruchomościami gmin. Studium diagnostyczno-statystyczne na przykładzie gmin województwa zachodniopomorskiego. Szczecin: Wyd. Naukowe US. 
Kucharska-Stasiak, E., Ledzion-Trojanowska, Z., Szopiński, J., Żelazowski, K. (2006). Znaczenie użytkowania wieczystego w gospodarowaniu zasobem Gminy Łódź. Olsztyn:

Towarzystwo Naukowe Nieruchomości.

Kwartnik-Pruc, A., Trembecka, A. (2015). Wybrane problemy aktualizacji opłat rocznych z tytułu użytkowania wieczystego na przykładzie Miasta Krakowa. Studia i Prace Wydziału Nauk Ekonomicznych i Zarządzania, 36 (1), 317-329.

Mach, Ł. (2014). Czynniki kształtujące wartość nieruchomości mieszkaniowych w kontekście uwarunkowań makro-, mikro- oraz ultraotoczenia. Econometrics, 4 (46), 52-61.

Rozporządzenie Rady Ministrów z 21.09.2004 w sprawie wyceny nieruchomości i sporządzania operatu szacunkowego. t.j. Dz.U. 2007, poz. 2109, z późn. zm.

Ustawa z 14.07.1961 o gospodarce terenami w miastach i osiedlach. Dz.U. nr 32, poz. 159. Ustawa z 23.04.1964 - Kodeks cywilny. t.j. Dz.U. 2014, poz. 121.

Ustawa z 21.08.1997 o gospodarce nieruchomościami. t.j. Dz.U. 2014, poz. 518.

Ustawa z 29.07.2005 o przekształceniu prawa użytkowania wieczystego w prawo własności. t.j. Dz.U. 2012, poz. 83.

Źróbek, R., Kuryj, J., Kuryj-Wysocka, O., (2015). Aktualizacja opłaty rocznej a obciążenia finansowe użytkowników wieczystych. Studia i Prace Wydziału Nauk Ekonomicznych i Zarządzania, 36 (1).

\title{
KOSZALIN DISTRICT IN YEARS 2010-2015 AS A CASE STUDY OF THE PERPETUAL USUFRUCT OF LANDS OWNED BY STATE TREASURY
}

\begin{abstract}
Perpetual usufruct is a property right that enables leasehold use of land owned by local or state governments. This form of law lies between a proprietorship and a limited property right. In this article properties owned by the State Treasury in years 2010-2015 in Koszalin district were analysed. In this period of time and in mentioned district from 473 (in 2010) to 414 (in 2015) properties were given for use under the right of perpetual usufruct and were located in the area of 11 communes. The aim of this paper is to analyse data concerning the number, surface, value of real estate given for use to different subjects under the right of perpetual usufruct and to analyse updates of perpetual usufruct. The research was conducted basing on the quantitative data obtained from the District Office in Koszalin.
\end{abstract}

Translated by Anna Dawid

Keywords: land perpetual usufruct, Koszalin district

JEL Codes: R52, K11, P14, H27 
